\title{
Nutritional value and physical and chemical characteristics of white mulberry tree using different conservation methods for ruminant feed
}

\author{
Valor nutricional e características físico-químicas da amoreira \\ branca sob diferentes formas de conservação para alimentação de \\ ruminantes
}

\author{
Américo Fróes Garcez Neto ${ }^{1 *}$; Janielen da Silva ${ }^{2}$; Eduardo Michelon do \\ Nascimento $^{3}$; Jean Carlos Steinmacher Lourenço ${ }^{4}$; Sergio Rodrigo Fernandes ${ }^{5}$
}

\begin{abstract}
This study was carried out to evaluate the white mulberry tree (Morus alba) as a feedstuff for ruminants in natura, as hay and as silage. A completely randomized design with five treatments and three replicates was used, where the treatments were five types of mulberry forage: (1) in natura after cutting; (2) hay; (3) silage of mulberry in natura; (4) silage of wilted mulberry and (5) silage of mulberry with ground ear corn. The content of crude protein (CP) did not differ between the silages (average of $19.03 \%$ of dry matter - DM). The CP content of the silages was higher than in mulberry hay $(15.26 \% \mathrm{DM})$ and similar to mulberry after cutting $(17.00 \% \mathrm{DM})$. The neutral detergent fiber (NDF) content did not differ between the silages (34.84\% DM on average), but the NDF of silage with ear corn was lower than the mulberry hay ( 33.77 vs. $39.36 \% \mathrm{DM}$ ). The acid detergent fiber (ADF) content did not differ between silages and mulberry hay (30.66\% DM on average). The lowest value for ADF was observed in the mulberry after cutting $(26.06 \% \mathrm{DM})$. The aerobic stability of the silages was not broken during the seven days of aerobic exposure. The $\mathrm{pH}$ of silage of mulberry in natura was similar to silage of wilted mulberry (4.80 on average), while the silage with ear corn showed a lower $\mathrm{pH}$ value (4.58) compared to the other silages. The buffering capacity (BC) did not differ between the silage with ear corn and silage of wilted mulberry (84.91 meq $100 \mathrm{~g} \mathrm{DM}^{-1}$ on average), while a lower value was observed for silage of mulberry in natura $\left(56.69\right.$ meq $\left.100 \mathrm{~g} \mathrm{DM}^{-1}\right)$. The highest value for ammonia nitrogen $\left(\mathrm{NH}_{3}-\mathrm{N}\right)$ was demonstrated in the silage of mulberry in natura $(13.08 \%$ total $\mathrm{N})$, and the lowest values were observed in the silage with ear corn and silage of wilted mulberry ( 7.49 and $9.58 \%$ total $\mathrm{N}$, respectively). Silage with $11 \%$ of ground ear corn is the best alternative use of white mulberry tree as forage for ruminant feeding, since this form presented low fiber content and a fermentative pattern suitable for the process of forage conservation.
\end{abstract}

Key words: Ensiling. Haymaking. Fermentative pattern. Moisture absorbents.

1 Prof., Departamento de Zootecnia, Universidade Federal do Paraná, UFPR, Setor Palotina, Palotina, PR, Brasil. E-mail: americo. garcez@ufpr.br

2 Discente, Curso de Doutorado do Programa de Pós-Graduação em Ciência Animal e Pastagens, Escola Superior de Agricultura "Luiz de Queiroz", ESALQ, Universidade de São Paulo, USP, Piracicaba, SP, Brasil. E-mail: janielen@hotmail.com

3 Discente, Curso de Mestrado do Programa de Pós-graduação em Ciência Animal, PPGCA, UFPR, Setor Palotina, Palotina, PR, Brasil. E-mail: edu.vetufpr@gmail.com

${ }^{4}$ Discente, Curso de Mestrado do Programa de Pós-Graduação em Zootecnia, Universidade Estadual de Maringá, UEM, Maringá, PR, Brasil. E-mail: jeancarloslsss@gmail.com

5 Pós-Doutorando, PPGCA, UFPR, Setor Palotina, Palotina, PR, Brasil. E-mail: srfernandes83@gmail.com

* Author for correspondence 


\section{Resumo}

Objetivou-se por meio deste estudo verificar a viabilidade do uso da amoreira branca (Morus alba) como forrageira na alimentação de ruminantes sob as formas in natura, de feno e de silagem. O delineamento experimental utilizado foi inteiramente casualizado com cinco tratamentos e três repetições, onde os tratamentos consistiram em cinco formas de utilização da amoreira como forrageira: (1) in natura sob corte; (2) feno; (3) silagem de amoreira in natura; (4) silagem de amoreira pré-murchada e (5) silagem de amoreira com adição de milho desintegrado com palha e sabugo (MDPS). Não houve diferença no teor de proteína bruta (PB) entre as silagens $(19,03 \%$ da MS). Os teores de PB das silagens foram maiores que do feno de amoreira $(15,26 \%$ da MS) e semelhantes ao da amoreira in natura $(17,00 \%$ da MS). O teor de fibra em detergente neutro (FDN) foi semelhante entre as silagens (média de 34,84\% da MS), porém, o teor de FDN da silagem com MDPS foi menor que o do feno $(33,77 v s .39,36 \%$ da MS). O teor de fibra em detergente ácido (FDA) foi semelhante entre as silagens e o feno de amoreira (30,66\% da MS). O menor valor de FDA foi observado na amoreira in natura (26,06\% da MS). Não houve quebra da estabilidade aeróbia das silagens no período de sete dias de aerobiose. Os valores de $\mathrm{pH}$ foram equivalentes entre as silagens de amoreira in natura e pré-murchada (média de 4,80). A silagem com MDPS apresentou menor valor de $\mathrm{pH}$ que as demais silagens $(4,58)$. A capacidade tampão (CT) foi semelhante para as silagens de amoreira com MDPS e pré-murchada (média de 84,91 meq $100 \mathrm{~g}$ de $\left.\mathrm{MS}^{-1}\right)$. O menor valor dessa variável foi encontrado na silagem de amoreira in natura $(56,69 \mathrm{meq} 100 \mathrm{~g}$ de $\left.\mathrm{MS}^{-1}\right)$. O maior teor de nitrogênio amoniacal $\left(\mathrm{N}^{-\mathrm{NH}_{3}}\right)$ foi verificado na silagem de amoreira in natura $\left(13,08 \%\right.$ do $\mathrm{N}$ total), enquanto nas silagens de amoreira pré-murchada e com MDPS os teores de $\mathrm{N}_{-} \mathrm{NH}_{3}$ foram baixos (7,49 e 9,58\% do $\mathrm{N}$ total). A silagem de amoreira branca com $11 \%$ de milho desintegrado com palha e sabugo é a melhor alternativa para a alimentação de ruminantes, pois apresenta baixo teor de fibra e padrão fermentativo desejável ao processo de conservação.

Palavras-chave: Absorventes de umidade. Ensilagem. Fenação. Padrão fermentativo.

\section{Introduction}

Livestock ranching is one of the most important activities for the economic and social development of countries with potential for generating agricultural commodities. In Brazil, this activity is characterized mostly by pasture production systems, with predominance of grasses of the genera Panicum spp. and Brachiaria spp. (FERRAZ; FELÍCIO, 2010). However, in all regions of the country there are degraded pasture areas, due to the high stocking rates that exceed the pasture support capacity (FAO, 2009).

Among the factors that affect livestock productivity, seasonality of food supply in the pastures stands out, with periods of high availability of quality forage (rainy season) alternating with periods in which plant growth is reduced (dry season). In these conditions, it is fundamental to adopt techniques that optimize land use and ensure satisfactory animal growth indices, such as grazing control, the use of alternative food for supplementation, and strategic exploitation of forage resources for herd feeding.

Mulberry (Morus sp.) represents an alternative food for ruminants; it is a fruit shrub-tree species traditionally used as food for the silkworm. Its characteristics include good productive capacity (16 to 18 tons dry matter - DM ha ${ }^{-1}$ ), high protein content (15 to $25 \% \mathrm{DM}$ as crude protein - CP), adequate balance of amino acids, low fiber content (less than 40\% DM as neutral detergent fiber - NDF), high energy content (more than $70 \% \mathrm{DM}$ as total digestible nutrients - TDN), high leaf digestibility (70 to $90 \%$ ), perennial growth and adaptation to various types of soils and climates (SCHMIDEK et al., 2002).

Mulberry leaves have a nutritional quality equivalent to that of concentrates, which categorizes it as a high quality forage. Among the Brazilian states, Paraná accounts for about $86 \%$ of the area 
planted with mulberry trees in the country, with the North and Northwest regions of the state being the areas where this crop predominates (ALMEIDA; FONSECA, 2002). The cultivation principles of mulberry trees for sericulture also apply to its cultivation for feeding ruminants, however, in the latter case, the frequency of cutting and the density of planting are intensified. If it is not viable to carry out frequent cuts, either due to field management or the operational costs of harvesting, the mulberry leaves can be harvested and conserved as silage and hay. These two forms of conservation allow preservation of the qualitative characteristics of the forage and guarantee a stock of food for the herd for periods of low pasture supply.

The efficiency of the ensiling process can be measured by the qualitative and quantitative losses of the ensiled mass, which are influenced by the characteristics of the plants and also by the harvest, compaction and fermentation in the silo (RIBEIRO et al., 2009). The total loss in the ensiling process can be up to $20 \%$ of the ensiled mass (McDONALD et al., 1991) and, of that total, about $6.1 \%$ to $24.6 \%$ loss occurs during the fermentation (ZOPOLLATTO et al., 2009). In order to improve the fermentation pattern of silage, techniques such as wilting and the use of additives have been used to increase the DM content of the material before ensiling and to promote a more pronounced drop in $\mathrm{pH}$, respectively (AZEVEDO et al., 2015).

The high nutritional value of mulberry also enables conservation in the form of hay. However, this species may present some drawbacks common to haymaking of shrub-tree species, such as excessive loss of leaves during drying. On the other hand, one advantage in haymaking these species is the greater speed of drying of leaves when compared with the majority of grasses. This reduces the time of exposure to possible inclement weather in the field, increasing the chances of harvesting material in a suitable state for conservation.

In view of the satisfactory production and nutritional characteristics and its potential use in ruminant feeding, this study aimed to verify the viability of using the white mulberry tree as fresh forage, silage or hay.

\section{Material and Methods}

The experiment was conducted at the Laboratory of Animal Nutrition (LANA), Federal University of Paraná (UFPR), Palotina, State of Paraná, Brazil. The material used was white mulberry (Morus alba L. var. multicaulis Miúra), aged three years and subjected to 3-4 annual cuts. Plants were grown at the Agricultural Institute of Paraná (IAPAR), Palotina Experimental Station. The climate of the region is characterized as subtropical, classified as Cfa according to the Köppen classification, with an average annual temperature of $22.35^{\circ} \mathrm{C}$ and relative humidity of $76.1 \%$.

Mulberry trees with an average height of $1.4 \mathrm{~m}$ were cut to a height of approximately $0.4 \mathrm{~m}$. At the time of cutting, October, plants had gone through approximately five months of growth since the previous standardization cut. The collected material was divided into three fractions. The first fraction was sampled to characterize the mulberry used as fresh forage. The second fraction was destined for haymaking, in which the material was exposed to the environment for drying for a period of $48 \mathrm{~h}$, on a black plastic sheet on a concrete floor without cover. The forage was turned twice within this period, $8 \mathrm{~h}$ and $16 \mathrm{~h}$ after the initial cut. The third fraction was ground in a stationary shredder generating particulate organic matter with a size of approximately $20 \mathrm{~mm}$ and ensiled in one of three ways: (a) fresh mulberry tree; (b) mulberry tree wilted in the sun for approximately $2.5 \mathrm{~h}$ (forage turned twice within the period at a one-hour interval); and (c) mulberry tree with ground ear corn, which is composed of kernel, husk and cob $(89 \% \mathrm{DM})$ and added at the time of ensiling at a proportion of $10.85 \%$ of total DM. In all three silage types, the harvested material comprised only leaves 
and petioles. The experimental silos were PVC tubes (150 $\mathrm{mm}$ in diameter and $600 \mathrm{~mm}$ in height) in which the material was compacted until reaching a density of $600 \mathrm{~kg}$ natural matter $(\mathrm{NM}) \mathrm{m}^{-3}$. After compaction, silos were sealed with adhesive tape and stored at the LANA until opening.

The experiment was a completely randomized design with five treatments and three replications, in which the treatments consisted of five types of mulberry forage: (1) fresh forage; (2) hay; (3) fresh mulberry silage; (4) pre-wilted mulberry silage and (5) mulberry silage with ear corn.

The nutritional composition of the fresh mulberry tree was evaluated on the day of the cutting and, for of hay, at the end of the drying process. Samples of fresh mulberry tree were dehydrated in a forced ventilation oven at $55^{\circ} \mathrm{C}$ for $72 \mathrm{~h}$. After drying, samples of mulberry tree and hay were ground in a Wiley mill with a $1 \mathrm{~mm}$ mesh sieve. The contents of DM, CP, ether extract (EE), lignin and ash were determined according to the procedures of the Association of Official Analytical Chemists (AOAC, 1990). The content of NDF and acid detergent fiber (ADF) were determined according to Van Soest et al. (1991). The hemicellulose content (HCel) was calculated as the difference between $\mathrm{NDF}$ and ADF, and the cellulose content (Cel) as the difference between ADF and lignin. The nonfiber carbohydrate (NFC) content was calculated using the equation: $100-(\mathrm{CP}+\mathrm{EE}+\mathrm{NDF}+\mathrm{Ash})$. The contents of TDN and digestible energy (DE) were determined according to Weiss et al. (1992).

After opening (day 52 after sealing), the silos remained open for seven days to determine the aerobic stability. This was evaluated by monitoring the temperature inside the silos (approximately at the spatial center of the ensiled mass) and outside of the silos. The temperature was measured with thermosensors inserted inside the silos and placed in the same room as silos, and were connected to a data storage center (HOBO Data Logger $\left.{ }^{\circledR}\right)$. The average temperatures inside the silos and of the ambient were recorded at 10 min intervals. The aerobic stability corresponded to the period in which the temperature of the ensiled mass increased by $2{ }^{\circ} \mathrm{C}$ in relation to the ambient temperature (TAYLOR; KUNG JÚNIOR, 2002).

The nutritional composition and fermentation characteristics of the silages were determined at the time of opening the silos and after seven days of aerobic exposure. For analysis of chemical composition, the same methods were used and the same components of the fresh mulberry tree evaluated as previously described. In turn, the fermentation characteristics were determined in samples of fresh silage (approximately $150 \mathrm{~g}$ ) collected from each silo. Samples were divided into subsamples for evaluation of the following characteristics: buffering capacity (BC) - measured in $15 \mathrm{~g}$ subsamples, according to Playne and McDonald (1966); $\mathrm{pH}$ - evaluated in $9 \mathrm{~g}$ subsamples, according to Silva and Queiroz (2002); electrical conductivity (EC) - measured in 25 g subsamples, according to Kraus et al. (1999); and ammonia nitrogen $\left(\mathrm{NH}_{3}-\mathrm{N}\right)$ - evaluated in $25 \mathrm{~g}$ subsamples, according to the procedures described by AOAC (1990).

Data on the nutritional composition of the different mulberry forages were subjected to analysis of variance and the mean values were compared using Tukey's test.

Data on temperature variation inside the silos in relation to the ambient and temperature inside the silos during aerobiosis were analyzed using a splitplot model, in which the type of silage was assigned to the plot and each day of aerobic exposure assigned to the subplot. The isolated effects of ensiling type and aerobic exposure time, as well as the interaction between the two factors, were tested using analysis of variance, and the mean values compared using Tukey's test.

Data on the nutritional composition and physical and chemical characteristics of the silages were also analyzed using a split-plot model, in which 
the type of silage was assigned to the plot and the initial and final days of aerobic exposure assigned to the subplot. The isolated effects of ensiling type and aerobic exposure time, as well as the interaction between the two factors, were tested using analysis of variance, and the mean values compared using Tukey's test.

Statistical analyses were performed using Statistical Analysis System software, version 9.0 (SAS, 2002), considering the significance of up to $5 \%$ of probability.

\section{Results and Discussion}

There was a significant effect $(\mathrm{P}<0.05)$ of the forms of mulberry utilization on the DM, CP, EE, NDF, ADF, HCel and Cel (Table 1). The haymaking process increased the DM content to $89.87 \%$, which is an appropriate value for this form of conservation, since is greater than the $80 \%$ reported by Merry et al. (2000) and Collins and Owens (2003). The wilting and the addition of ear corn increased the DM content of silages to the appropriate value for the fermentation process (35.61 and 30.09\%, respectively), while the fresh mulberry tree silage had DM content (24.05\%) below the value considered to be ideal for fermentation, which is 28 to $40 \%$ as reported by Jobim and Nussio (2013). Increasing the DM content of the ensiled material is a strategy that aims to reduce the loss of soluble nutrients through effluent during fermentation. Carvalho et al. (2007) assessed the nutritional value of elephant grass silage wilted with the addition of cocoa meal, and found that wilting reduced the moisture content and enabled the production of silage with adequate quality.

Table 1. Chemical characteristics of white mulberry tree in five types of ruminant feed.

\begin{tabular}{|c|c|c|c|c|c|c|c|}
\hline \multirow{2}{*}{ Variable ${ }^{\mathrm{I}}$} & \multirow{2}{*}{$\begin{array}{c}\text { Mulberry in } \\
\text { natura }\end{array}$} & \multirow{2}{*}{ Hay } & \multicolumn{3}{|c|}{ Silage $^{\mathrm{II}}$} & \multirow{2}{*}{$\mathrm{CV}^{\mathrm{IIII}}(\%)$} & \multirow{2}{*}{$P$-value } \\
\hline & & & $\mathrm{MN}$ & MW & ME & & \\
\hline $\mathrm{DM}^{\mathrm{IV}}$ & $25.44 \mathrm{~d}$ & $89.87 \mathrm{a}$ & $24.05 \mathrm{e}$ & $35.61 \mathrm{~b}$ & $30.09 \mathrm{c}$ & 62.57 & $<0.0001$ \\
\hline $\mathrm{CP}^{\mathrm{V}}$ & $17.00 \mathrm{ab}$ & $15.26 \mathrm{~b}$ & $18.83 \mathrm{a}$ & $19.29 \mathrm{a}$ & $18.99 \mathrm{a}$ & 10.31 & 0.0053 \\
\hline $\mathrm{EE}^{\mathrm{V}}$ & $2.33 \mathrm{~b}$ & $1.35 \mathrm{c}$ & $2.96 \mathrm{ab}$ & $2.43 \mathrm{~b}$ & $3.30 \mathrm{a}$ & 29.16 & $<0.0001$ \\
\hline $\mathrm{NDF}^{\mathrm{V}}$ & $34.00 \mathrm{ab}$ & $39.36 \mathrm{a}$ & $34.41 \mathrm{ab}$ & $36.34 \mathrm{ab}$ & $33.77 \mathrm{~b}$ & 7.90 & 0.0424 \\
\hline $\mathrm{ADF}^{\mathrm{V}}$ & $26.06 \mathrm{~b}$ & $30.69 \mathrm{a}$ & $31.98 \mathrm{a}$ & $31.84 \mathrm{a}$ & $28.11 \mathrm{ab}$ & 9.33 & 0.0058 \\
\hline $\mathrm{HCel}^{\mathrm{V}}$ & $7.93 \mathrm{a}$ & $8.68 \mathrm{a}$ & $2.43 \mathrm{~b}$ & $4.50 \mathrm{ab}$ & $5.66 \mathrm{ab}$ & 47.69 & 0.0087 \\
\hline Cellulose $^{\mathrm{V}}$ & $22.00 \mathrm{~b}$ & $26.34 \mathrm{ab}$ & $27.45 \mathrm{ab}$ & $29.04 \mathrm{a}$ & $25.29 \mathrm{ab}$ & 12.23 & 0.0455 \\
\hline Lignin $^{V}$ & 4.06 & 4.35 & 4.53 & 2.80 & 2.82 & 38.76 & 0.4375 \\
\hline $\mathrm{Ash}^{\mathrm{V}}$ & 9.33 & 8.79 & 8.76 & 9.08 & 8.08 & 8.21 & 0.3062 \\
\hline $\mathrm{NFC}^{\mathrm{V}}$ & 37.35 & 35.25 & 35.04 & 32.87 & 35.85 & 6.36 & 0.1685 \\
\hline $\mathrm{TDN}^{\mathrm{V}}$ & 60.13 & 58.77 & 60.36 & 61.79 & 64.04 & 4.89 & 0.2562 \\
\hline $\mathrm{DE}^{\mathrm{VI}}$ & 2.64 & 2.55 & 2.67 & 2.73 & 2.84 & 5.04 & 0.0731 \\
\hline
\end{tabular}

${ }^{\mathrm{I}} \mathrm{DM}$ : dry matter; CP: crude protein; EE: ether extract; NDF: neutral detergent fiber; ADF: acid detergent fiber; HCel: hemicellulose; NFC: non-fibrous carbohydrate; TDN: total digestible nutrients; DE: digestible energy.

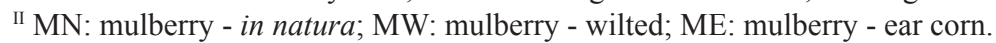

${ }^{\text {III }} \mathrm{CV}$ : coefficient of variation; ${ }^{\mathrm{IV}} \%$ of natural matter; ${ }^{\mathrm{V}} \%$ of $\mathrm{DM}$; ${ }^{\mathrm{VI}} \mathrm{Mcal} \mathrm{kg}$ of $\mathrm{DM}^{-1}$.

Mean values followed by different lowercase letters in the row differ by Tukey's test $(\mathrm{P}<0.05)$. 
The $\mathrm{CP}$ content showed no difference $(\mathrm{P}>0.05)$ between silages, with a mean value of $19.03 \% \mathrm{DM}$ (Table 1). However, the CP content of silages was higher $(\mathrm{P}<0.05)$ than that of the mulberry tree hay (15.26\% DM). Probably, the lower CP content of hay is related to dehydration of the material, which resulted in volatilization of nitrogen compounds. In this case, the decrease in CP content is attributed to loss of nitrogen compounds in the form of ammonia, which occurs during hay drying at high ambient temperature (TAFFAREL et al., 2014). The use of additives and the practice of wilting are techniques that can preserve and increase the CP content of the ensiled material. Evangelista et al. (2009), evaluating the addition of ear corn to sugarcane silages, observed that $\mathrm{CP}$ content increased by an average of 1.13 percentage points with the use of this additive, improving the nutritional composition of silage. The CP content of fresh mulberry tree $(17.0 \% \mathrm{DM})$ was similar to that found in all silages evaluated here, showing that the ensiling process is a good alternative for preserving mulberry tree protein.

The EE content showed similar values $(\mathrm{P}>0.05)$ between the silages of fresh mulberry tree and with addition of ear corn (2.96 vs. 3.30\% DM). However, the value of this variable in silage with ear corn was higher than in pre-wilted mulberry silage (3.30 vs. $2.43 \% \mathrm{DM}$ ), which is explained by the decrease in EE content during the wilting process, where lipid pigments are degraded by high luminosity and temperature, and by the higher EE content in ear corn in relation to mulberry tree (5.16 vs. $2.10 \%$ $\mathrm{DM})$. There was a difference $(\mathrm{P}<0.05)$ between the $\mathrm{EE}$ content of hay and other forms of utilization, with hay having a lower value for this variable $(1.35 \% \mathrm{DM})$. The increase in the exposure time to luminosity for the material subjected to haymaking is a factor that contributed to this decrease.

The NDF content of the silages was similar (P $>0.05$ ), with a mean value of $34.84 \%$ DM (Table 1). However, the NDF content of silage with ear corn was lower $(\mathrm{P}<0.05)$ than that of hay $(33.77$ vs. $39.36 \% \mathrm{DM})$. This difference was also reported by Evangelista et al. (2009), who verified that the inclusion of ear corn in sugarcane silage decreased the NDF content by 17.8 percentage points compared to the control silage (57.8vs. $75.6 \%$, respectively).

The ADF content of the silages and hay were similar $(\mathrm{P}>0.05)$, with a mean value of $30.66 \% \mathrm{DM}$ (Table 1). However, there was a difference $(\mathrm{P}<0.05)$ between the two methods of conservation and the fresh mulberry tree, which presented the lowest ADF content $(26.06 \% \mathrm{DM})$. The higher contents of ADF of silages and hay were related to conservation processes, in which fermentation and drying during ensiling and haymaking, respectively, resulted in loss of soluble components (protein, minerals, NFC) and raised the levels of fiber components, such as the ADF.

There was no difference $(\mathrm{P}>0.05)$ in $\mathrm{HCel}$ between the silages, with a mean value of $4.19 \%$ DM (Table 1). Nevertheless, the HCel content found in fresh mulberry tree silage $(2.43 \%)$ was lower ( $\mathrm{P}$ $<0.05$ ) than in hay and fresh mulberry tree (8.68 and $7.93 \%$ DM, respectively). A possible cause for the lower values of $\mathrm{HCel}$ in silage is the degradation of this nutrient by acid and enzymatic hydrolysis during the fermentation process. McDonald et al. (1991) reported that the enzymes produced by bacteria present in the forage during fermentation can break the chemical bonds of fiber carbohydrates, mainly HCel. In turn, with regard to Cel content, it was verified that pre-wilted mulberry tree silage had a higher content $(\mathrm{P}<0.05)$ of this component compared to its fresh form (29.04 vs. $22.00 \% \mathrm{DM}$ ), because in the ensiling process there is loss of NFC, thus increasing the proportion of fiber carbohydrates in the ensiled material. The variation in Cel content was similar to the variation in ADF content between the different types of mulberry forage that were evaluated.

Content of lignin, ash, NFC, TDN and DE were similar $(\mathrm{P}>0.05)$ in the different types of mulberry forage (Table 1 ), with mean values of 
3.71, 8.81, 35.27 and 61.02\% DM, and 2.69 Mcal kg $\mathrm{DM}^{-1}$, respectively. Mulberry may be considered an important food for ruminants because it presents low levels of fiber carbohydrates and lignin, and high levels of NFC, TDN and DE. This nutritional profile confers high digestibility on this plant compared to other forage species (DORAN et al., 2007), which allows more efficient utilization by the animals and reduces the need for protein supplementation (SALINAS-CHAVIRA et al., 2011).
There was a difference $(\mathrm{P}<0.05)$ in mean internal temperature of the silos at different timepoints during the period of aerobiosis (Table 2). The temperature reached the highest value (29.16 ${ }^{\circ} \mathrm{C}$ ) on the second day and the lowest value (24.51 ${ }^{\circ} \mathrm{C}$ ) on the fourth day of aerobic exposure (Table 3 and Figure 1). On the second and fourth day, the mean ambient temperature was 29.14 and $24.32{ }^{\circ} \mathrm{C}$, respectively.

Table 2. Values of probability for the fixed effects of ensiling type and period of aerobic exposure, and their interactions with the silo temperature, chemical and physical characteristics of white mulberry tree silages.

\begin{tabular}{lccc}
\hline \multicolumn{1}{c}{ Variable } & \multicolumn{3}{c}{$P$-value } \\
\cline { 2 - 4 } & Ensiling type & $\begin{array}{c}\text { Aerobic } \\
\text { exposure }\end{array}$ & $\begin{array}{c}\text { Ensiling type } \times \\
\text { Aerobic exposure }\end{array}$ \\
\hline $\begin{array}{l}\text { Silo temperatures } \\
\text { Variation of temperature inside the silos }\end{array}$ & 0.8280 & $<0.0001$ & 0.3049 \\
$\quad$ Temperature inside the silos & 0.6502 & $<0.0001$ & 0.6213 \\
\hline Content of dry matter, non-fibrous components and energy & & & \\
Dry matter & 0.0001 & 0.0354 & 0.4043 \\
Crude protein & 0.6232 & 0.1054 & 0.1916 \\
Ether extract & 0.0008 & 0.0783 & 0.8331 \\
Ash & 0.0170 & 0.1518 & 0.0359 \\
Non-fibrous carbohydrates & 0.0764 & 0.8371 & 0.4645 \\
Total digestible nutrients & 0.1753 & 0.3986 & 0.7709 \\
Digestible energy & 0.1425 & 0.5422 & 0.6436 \\
\hline Content of fibrous components & & & \\
Neutral detergent fiber & 0.0253 & 0.5591 & 0.4384 \\
Acid detergent fiber & 0.0050 & 0.5834 & 0.1596 \\
Hemicellulose & 0.0490 & 0.8991 & 0.7214 \\
Celullose & 0.0084 & 0.3923 & 0.3439 \\
Lignin & 0.4503 & 0.4774 & 0.4870 \\
\hline Physical-chemical characteristics & & & \\
pH & 0.0122 & 0.1505 & 0.1816 \\
Buffering capacity & 0.0067 & 0.9022 & 0.6205 \\
Electrical conductivity & 0.0369 & 0.4559 & 0.5684 \\
Ammonia nitrogen & 0.0033 & 0.0251 & 0.7256 \\
\hline
\end{tabular}


Table 3. Variation of temperature inside the silos in relation to the ambient temperature $\left(\mathrm{VTemp} ;{ }^{\circ} \mathrm{C}\right)$ and temperature inside the silos $\left(\mathrm{Temp} ;{ }^{\circ} \mathrm{C}\right)$ of white mulberry tree silages during the period of aerobic exposure.

\begin{tabular}{lcccccccc}
\hline \multirow{2}{*}{ Variable } & \multirow{2}{*}{ Silage $^{\mathrm{I}}$} & \multicolumn{7}{c}{ Time (days) } \\
\cline { 3 - 9 } & & 1 & 2 & 3 & 4 & 5 & 6 & 7 \\
\hline \multirow{4}{*}{ VTemp } & MN & 0.07 & 0.12 & 1.63 & 0.25 & 0.51 & 0.78 & 1.15 \\
& MW & -0.02 & -0.10 & 1.08 & -0.14 & 0.04 & 0.24 & 0.53 \\
& ME & 0.00 & 0.03 & 1.68 & 0.45 & 0.80 & 1.04 & 1.54 \\
\cline { 2 - 9 } & Mean & $0.02 \mathrm{~d}$ & $0.02 \mathrm{~d}$ & $1.46 \mathrm{a}$ & $0.19 \mathrm{~d}$ & $0.45 \mathrm{c}$ & $0.69 \mathrm{bc}$ & $1.07 \mathrm{ab}$ \\
\hline \multirow{4}{*}{ Temp } & MN & 27.32 & 29.26 & 27.76 & 24.57 & 25.74 & 25.29 & 24.68 \\
& MW & 27.23 & 29.04 & 27.21 & 24.18 & 25.28 & 24.75 & 24.06 \\
& ME & 27.25 & 29.17 & 27.80 & 24.77 & 26.03 & 25.55 & 25.07 \\
\hline & Mean & $27.27 \mathrm{~b}$ & $29.16 \mathrm{a}$ & $27.59 \mathrm{~b}$ & $24.51 \mathrm{~d}$ & $25.68 \mathrm{c}$ & $25.20 \mathrm{c}$ & $24.61 \mathrm{~d}$ \\
\hline
\end{tabular}

${ }^{\mathrm{I}} \mathrm{MN}$ : mulberry - in natura; MW: mulberry - wilted; ME: mulberry - ear corn.

Mean values followed by different lowercase letters in the row differ by Tukey's test $(\mathrm{P}<0.05)$.

Figure 1. Variation of temperature inside the silos in relation to the ambient temperature (A), and ambient temperature and temperature inside the silos (B) of white mulberry silages.
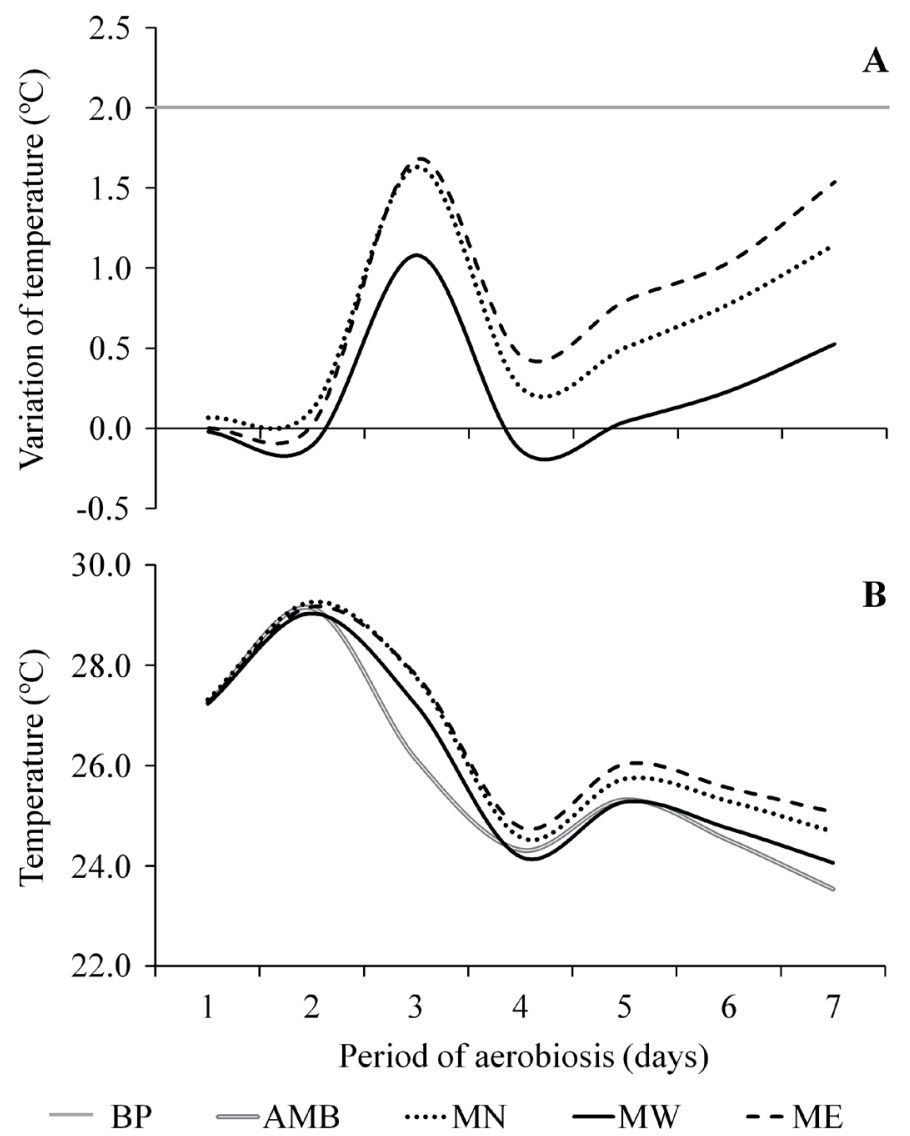

BP: break point of aerobic stability; AMB: ambient temperature; MN: mulberry - in natura; MW: mulberry - wilted; ME: mulberry - ear corn. 
Despite the variation in the internal temperature of the silos in relation to the ambient temperature, there was no break in the aerobic stability of the silages. According to Taylor and Kung Júnior (2002) and Tabacco et al. (2009), the aerobic stability process is defined as the number of hours in which the silage is exposed to the air before there is an increase of $2{ }^{\circ} \mathrm{C}$ in the silo temperature in relation to the ambient temperature. In agreement with McDonald et al. (1991), the growth of aerobic microorganisms causes an increase in temperature and, consequently, an increase in the loss of nutrients from the ensiled forage. During the seven days after opening of the silos, there was no difference greater than $2^{\circ} \mathrm{C}$ between the internal temperature of the silo and the ambient temperature in the three types of mulberry tree silage (Table 3 and Figure 1). This is due to the low exposure of NFC in the ensiled material during the aerobiosis period, indicating that this nutritional fraction was conserved in the forage and was not used by spoilage microorganisms present in the silos.

The threshold temperature of aerobic stability breaking (break point - BP) was not reached in the three types of silage, however, the pre-wilted mulberry tree silage presented lower temperature variation than the others (Table 3 and Figure 1A). Although there was no significant difference between the three silages in terms of the temperature variation inside the silos in relation to ambient temperature, the lower variation recorded for the pre-wilted mulberry silage indicates that the wilting process was effective in keeping the ensiled material near the ambient temperature, providing better preservation of the nutrients present in the silage.

The mean DM content during the aerobiosis period was different $(\mathrm{P}<0.05)$ between mulberry tree silages (Table 2), with higher, intermediate and lower values for pre-wilted mulberry silage (35.86\%), mulberry with ear corn (30.32\%) and fresh mulberry tree (24.49\%; Table 4). As with ear corn, the addition of ingredients with a high DM content, such as wheat bran and ground corn, to high moisture forage silage is an efficient technique for increasing the DM content of silage and reducing losses as gas and effluents, since forages with high moisture content facilitate the development of bacteria of the genus Clostridium and create an environment which is unfavorable to the growth of acid-lactic bacteria (ZANINE et al., 2006; ANDRADE et al., 2012). In addition, wilting and ear corn addition favored the stability of silage during the aerobiosis period, reducing the variation in DM content compared to fresh mulberry tree silage ( 0.50 and 0.46 vs. 0.88 percentage points, respectively). 
Table 4. Content of dry matter, non-fibrous components and energy in white mulberry silages at the time of silo opening (day 0 ) and after aerobic exposure (day 7 ).

\begin{tabular}{|c|c|c|c|c|c|c|}
\hline \multirow{2}{*}{ Variable $^{\mathrm{I}}$} & \multirow{2}{*}{$\begin{array}{l}\text { Time } \\
\text { (days) }\end{array}$} & \multicolumn{3}{|c|}{ Silage"II } & \multirow{2}{*}{ Mean } & \multirow{2}{*}{$\mathrm{CV}^{\mathrm{III}}(\%)$} \\
\hline & & $\mathrm{MN}$ & MW & $\mathrm{ME}$ & & \\
\hline \multirow{3}{*}{$\mathrm{DM}^{\mathrm{IV}}$} & 0 & 24.05 & 35.61 & 30.09 & $29.91 \mathrm{~b}$ & \multirow{3}{*}{16.77} \\
\hline & 7 & 24.93 & 36.11 & 30.55 & $30.53 \mathrm{a}$ & \\
\hline & Mean & $24.49 \mathrm{C}$ & $35.86 \mathrm{~A}$ & $30.32 \mathrm{~B}$ & 30.22 & \\
\hline \multirow{3}{*}{$\mathrm{CP}^{\mathrm{V}}$} & 0 & 18.83 & 19.29 & 18.99 & 19.04 & \multirow{3}{*}{8.91} \\
\hline & 7 & 19.22 & 16.62 & 17.87 & 17.90 & \\
\hline & Mean & 19.03 & 17.96 & 18.43 & 18.47 & \\
\hline \multirow{3}{*}{$\mathrm{EE}^{\mathrm{V}}$} & 0 & 2.96 & 2.43 & 3.30 & 2.90 & \multirow{3}{*}{13.73} \\
\hline & 7 & 3.07 & 2.66 & 3.52 & 3.08 & \\
\hline & Mean & $3.02 \mathrm{~B}$ & $2.54 \mathrm{C}$ & $3.41 \mathrm{~A}$ & 2.99 & \\
\hline \multirow{3}{*}{$\mathrm{Ash}^{\mathrm{V}}$} & 0 & $8.76 \mathrm{Aa}$ & $9.08 \mathrm{Ab}$ & $8.08 \mathrm{Aa}$ & 8.64 & \multirow{3}{*}{11.35} \\
\hline & 7 & $9.41 \mathrm{Aa}$ & $9.67 \mathrm{Aa}$ & $7.23 \mathrm{Ba}$ & 8.77 & \\
\hline & Mean & 9.08 & 9.38 & 7.66 & 8.71 & \\
\hline \multirow{3}{*}{$\mathrm{NFC}^{\mathrm{V}}$} & 0 & 35.04 & 32.87 & 35.85 & 34.59 & \multirow{3}{*}{9.11} \\
\hline & 7 & 33.31 & 32.81 & 38.53 & 34.88 & \\
\hline & Mean & 34.17 & 32.84 & 37.19 & 34.74 & \\
\hline \multirow{3}{*}{$\mathrm{TDN}^{\mathrm{V}}$} & 0 & 60.36 & 61.79 & 64.04 & 62.06 & \multirow{3}{*}{4.12} \\
\hline & 7 & 62.43 & 61.91 & 64.83 & 63.06 & \\
\hline & Mean & 61.40 & 61.85 & 64.44 & 62.56 & \\
\hline \multirow{3}{*}{$\mathrm{DE}^{\mathrm{VI}}$} & 0 & 2.67 & 2.73 & 2.84 & 2.75 & \multirow{3}{*}{4.00} \\
\hline & 7 & 2.77 & 2.71 & 2.86 & 2.78 & \\
\hline & Mean & 2.72 & 2.72 & 2.85 & 2.76 & \\
\hline
\end{tabular}

${ }^{I}$ DM: dry matter; CP: crude protein; EE: ether extract; NFC: non-fibrous carbohydrate; TDN: total digestible nutrients; DE: digestible energy. ${ }^{\text {II }} \mathrm{MN}$ : mulberry - in natura; MW: mulberry - wilted; ME: mulberry - ear corn. ${ }^{\text {III }} \mathrm{CV}$ : coefficient of variation; ${ }^{\text {IV\%}} \%$ of natural matter; ${ }^{\mathrm{V}} \%$ of DM; ${ }^{\mathrm{VI}} \mathrm{Mcal} \mathrm{kg}$ of $\mathrm{DM}^{-1}$. Mean values followed by different lowercase letters in the column and different uppercase letters in the row differ by Tukey's test $(\mathrm{P}<0.05)$.

The mean EE content during the aerobiosis period showed significant differences $(\mathrm{P}<0.05)$ between the three silages (Table 2), with higher, intermediate and lower values for mulberry silage with ear corn (3.41\% DM), fresh mulberry $(3.02 \%$ DM) and pre-wilted mulberry $(2.54 \%$ DM; Table 4). However, the EE content of the three silages was not influenced $(\mathrm{P}>0.05)$ by aerobic exposure time, indicating that this nutrient was preserved in the plant when kept under conditions of aerobiosis.

There was interaction $(\mathrm{P}<0.05)$ between ensiling types and aerobiosis during for ash content of mulberry silages (Table 2). The ash content was similar between the silages at the time of opening the silos (mean of $8.64 \% \mathrm{DM}$ ), however, there was an increase of 0.59 percentage points in the content of this nutrient in the pre-wilted mulberry silage during the aerobiosis period (9.08 to $9.67 \%$ DM; Table 4). This increase is related to the low solubility of minerals in this silage, indicating that these nutrients were preserved in the plant, and not exposed to and used by spoilage microorganisms during the aerobiosis period. At the end of this period, mulberry silage with ear corn had lower ash content compared to the other silages ( 7.23 vs. $9.54 \% \mathrm{DM}$, on average). This is explained by the lower ash content of ear corn compared to the mulberry tree at the time of ensiling (2.71 vs. $8.78 \%$ DM) and possibly due to the higher solubility of minerals in the silage with ear corn compared to the other silages. In this case, the greater loss of minerals from silage with ear corn may be related to the use of these nutrients by spoilage microorganisms during the aerobiosis period. 
There was no effect of ensiling types and aerobiosis duration $(\mathrm{P}>0.05)$ on content of $\mathrm{CP}, \mathrm{NFC}$, TDN and DE (Table 2), which had mean values of 18.47 ; $34.74 ; 62.56 \% \mathrm{DM}$, and $2.76 \mathrm{Mcal} \mathrm{kg} \mathrm{DM}^{-1}$, respectively (Table 4). Therefore, regardless of the type of silage, there was no decrease in the quality of the ensiled material after seven days of aerobic exposure, which indicates that mulberry is a plant with great potential for ensiling.

The mean contents of NDF and ADF during the aerobiosis period were significantly different ( $P$ $<0.05$ ) between the silages (Table 2). NDF content was higher in pre-wilted mulberry silage $(37.29 \%$ DM) than in the others, which were similar to each other (mean of $34.00 \%$ DM; Table 5). This is explained by increase in the content of the fiber fraction in response to the wilting process before ensiling. In turn, the ADF content of silages of fresh mulberry and pre-wilted mulberry were not different from each other (mean of $32.43 \%$ DM) but were higher than that of silage containing ear corn $(27.67 \%$ DM). In this case, the lower ADF content of ear corn compared to that of mulberry (11.08 vs. $25.17 \% \mathrm{DM}$ ) determined the lower content of this fiber fraction in silage containing ear corn. Lignin content was not influenced $(\mathrm{P}>0.05)$ by ensiling type or aerobiosis period (Table 2), with a mean value of $3.12 \%$ DM (Table 5 ).

The mean HCel content in the aerobiosis period was higher $(\mathrm{P}<0.05)$ in silage with ear corn compared to fresh mulberry silage (5.64 vs. $2.98 \%$ DM, Table 5). However, the mean content of Cel in the aerobiosis period was lower in silage with ear corn compared to pre-wilted mulberry silage (24.69 vs. $30.41 \% \mathrm{DM})$. This was due to the high content of $\mathrm{HCel}$ and the low content of $\mathrm{Cel}$ in the ear corn (20.69 and $8.46 \%$ DM, respectively) compared to the mulberry at the time of ensiling $(6.61 \%$ and $22.03 \%$ DM, respectively). The profile of fiber components of the three silages evaluated indicates that mulberry silage with ear corn showed a higher potential for use by ruminants, since the higher $\mathrm{HCel}$ content and lower Cel content promotes higher digestibility.

Table 5. Content of fibrous components in white mulberry silages at the time of silo opening (day 0 ) and after aerobic exposure (day 7).

\begin{tabular}{|c|c|c|c|c|c|c|}
\hline \multirow{2}{*}{ Variable $^{\mathrm{I}}$} & \multirow{2}{*}{$\begin{array}{c}\text { Time } \\
\text { (days) }\end{array}$} & \multicolumn{3}{|c|}{ Silage $^{\mathrm{II}}$} & \multirow{2}{*}{ Mean } & \multirow{2}{*}{$\begin{array}{c}\mathrm{CV}^{\mathrm{III}} \\
(\%)\end{array}$} \\
\hline & & $\mathrm{MN}$ & MW & $\mathrm{ME}$ & & \\
\hline \multirow{3}{*}{$\mathrm{NDF}^{\mathrm{IV}}$} & 0 & 34.41 & 36.34 & 33.77 & 34.84 & \multirow{3}{*}{6.75} \\
\hline & 7 & 34.99 & 38.24 & 32.85 & 35.36 & \\
\hline & Mean & $34.70 \mathrm{~B}$ & $37.29 \mathrm{~A}$ & $33.31 \mathrm{~B}$ & 35.10 & \\
\hline \multirow{3}{*}{$\mathrm{ADF}^{\mathrm{IV}}$} & 0 & 31.98 & 31.84 & 28.11 & 30.64 & \multirow{3}{*}{9.34} \\
\hline & 7 & 31.47 & 34.43 & 27.23 & 31.04 & \\
\hline & Mean & $31.73 \mathrm{~A}$ & $33.14 \mathrm{~A}$ & $27.67 \mathrm{~B}$ & 30.84 & \\
\hline \multirow{3}{*}{$\mathrm{HCel}^{\mathrm{IV}}$} & 0 & 2.43 & 4.50 & 5.66 & 4.20 & \multirow{3}{*}{43.23} \\
\hline & 7 & 3.53 & 3.80 & 5.62 & 4.32 & \\
\hline & Mean & $2.98 \mathrm{~B}$ & $4.15 \mathrm{AB}$ & $5.64 \mathrm{~A}$ & 4.26 & \\
\hline \multirow{3}{*}{ Cellulose $^{\mathrm{IV}}$} & 0 & 27.45 & 29.04 & 25.29 & 27.26 & \multirow{3}{*}{11.36} \\
\hline & 7 & 28.72 & 31.79 & 24.09 & 28.20 & \\
\hline & Mean & $28.09 \mathrm{AB}$ & $30.41 \mathrm{~A}$ & $24.69 \mathrm{~B}$ & 27.73 & \\
\hline \multirow{3}{*}{$\operatorname{Lignin}^{\mathrm{IV}}$} & 0 & 4.53 & 2.80 & 2.82 & 3.38 & \multirow{3}{*}{42.54} \\
\hline & 7 & 2.75 & 2.65 & 3.15 & 2.85 & \\
\hline & Mean & 3.64 & 2.72 & 2.99 & 3.12 & \\
\hline
\end{tabular}

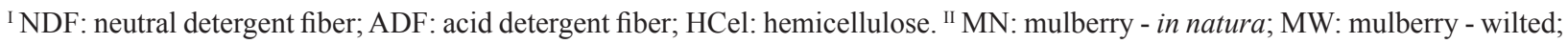
ME: mulberry - ear corn. ${ }^{\text {III }} \mathrm{CV}$ : coefficient of variation; ${ }^{\mathrm{IV}} \%$ of dry matter.

Mean values followed by different uppercase letters in the row differ by Tukey's test $(\mathrm{P}<0.05)$. 
The mean $\mathrm{pH}$ value during the aerobiosis period showed significant difference $(\mathrm{P}<0.05)$ between the silages (Table 2), with higher values for the fresh and pre-wilted mulberry silages, which were similar to each other (mean of 4.80), and lower for silage with ear corn (4.58; Table 6). The addition of ear corn contributed to the supply of NFC, favoring lactic fermentation and a drop in $\mathrm{pH}$, without causing a change in this variable after opening the silos. In all silages there was no change in $\mathrm{pH}(\mathrm{P}>0.05)$ at the end of the aerobiosis period, indicating good conservation of the material after opening the silos. According to Andrade et al. (2012), inclusion of ground corn is a good alternative for increasing DM content, reducing effluent losses and improving the fermentation pattern of silages with high moisture content, keeping the $\mathrm{pH}$ of the ensiled mass low during the fermentation period and upon opening the silo.
The mean value of $\mathrm{BC}$ during the aerobiosis period showed a difference $(\mathrm{P}<0.05)$ between the silages (Table 2), with higher values for mulberry silage with ear corn and pre-wilted mulberry silage, which were similar to each other (mean $84.91 \mathrm{meq}$ $100 \mathrm{~g} \mathrm{DM}^{-1}$ ), and lower for the fresh mulberry silage (56.69 meq $100 \mathrm{~g} \mathrm{DM}^{-1}$; Table 6). The BC values for all silages are higher than those reported by McDonald and Henderson (1962) with silage made from perennial and legume grasses (30.76 and $55.62 \mathrm{meq} 100 \mathrm{~g} \mathrm{DM}^{-1}$, respectively). Rangrab et al. (2000), when evaluating alfalfa silage with $\mathrm{CP}$ content similar to that of the mulberry tree used in this study (18.94 vs. 18.47\% DM, respectively), reported a value of $54.05 \mathrm{meq} 100 \mathrm{~g} \mathrm{DM}^{-1}$. Thus, the high $\mathrm{BC}$ values recorded for silages in the present study (56.69 to $92.87 \mathrm{meq} 100 \mathrm{~g} \mathrm{DM}^{-1}$ ) are explained by the high protein content of the mulberry.

Table 6. Physical-chemical characteristics of white mulberry silages at the time of silo opening (day 0 ) and after aerobic exposure (day 7).

\begin{tabular}{|c|c|c|c|c|c|c|}
\hline \multirow{2}{*}{ Variable ${ }^{\mathrm{I}}$} & \multirow{2}{*}{$\begin{array}{l}\text { Time } \\
\text { (days) }\end{array}$} & \multicolumn{3}{|c|}{ Silage } & \multirow{2}{*}{ Mean } & \multirow{2}{*}{$\mathrm{CV}^{\mathrm{III}}(\%)$} \\
\hline & & $\mathrm{MN}$ & MW & ME & & \\
\hline \multirow{3}{*}{$\mathrm{pH}^{\mathrm{IV}}$} & 0 & 4.85 & 4.88 & 4.55 & 4.76 & \multirow{3}{*}{3.14} \\
\hline & 7 & 4.70 & 4.76 & 4.60 & 4.69 & \\
\hline & Mean & $4.78 \mathrm{~A}$ & $4.82 \mathrm{~A}$ & $4.58 \mathrm{~B}$ & 4.72 & \\
\hline \multirow{3}{*}{$\mathrm{BC}^{\mathrm{V}}$} & 0 & 59.23 & 93.96 & 74.17 & 75.78 & \multirow{3}{*}{23.78} \\
\hline & 7 & 54.15 & 91.79 & 79.72 & 75.22 & \\
\hline & Mean & $56.69 \mathrm{~B}$ & $92.87 \mathrm{~A}$ & $76.95 \mathrm{~A}$ & 75.50 & \\
\hline \multirow{3}{*}{$\mathrm{EC}^{\mathrm{VI}}$} & 0 & 1012.83 & 1206.00 & 944.27 & 1054.37 & \multirow{3}{*}{13.56} \\
\hline & 7 & 1145.33 & 1179.67 & 978.43 & 1101.14 & \\
\hline & Mean & $1079.08 \mathrm{AB}$ & $1192.83 \mathrm{~A}$ & $961.35 \mathrm{~B}$ & 1077.76 & \\
\hline \multirow{3}{*}{$\mathrm{NH}_{3}-\mathrm{N}^{\mathrm{VII}}$} & 0 & 12.58 & 6.69 & 8.55 & $9.27 \mathrm{~b}$ & \multirow{3}{*}{27.66} \\
\hline & 7 & 13.58 & 8.29 & 10.60 & $10.82 \mathrm{a}$ & \\
\hline & Mean & $13.08 \mathrm{~A}$ & $7.49 \mathrm{C}$ & $9.58 \mathrm{~B}$ & 10.05 & \\
\hline
\end{tabular}

${ }^{\mathrm{I}} \mathrm{BC}$ : buffering capacity; EC: electrical conductivity; $\mathrm{NH}_{3}-\mathrm{N}$ : ammonia nitrogen.

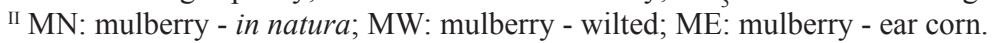

${ }^{\mathrm{III}} \mathrm{CV}$ : coefficient of variation; ${ }^{\mathrm{IV}} 1$ to $14 ;{ }^{\mathrm{V}} \mathrm{meq} 100 \mathrm{~g}$ of dry matter-1. ${ }^{\mathrm{VI}} \mathrm{mS} \mathrm{cm}{ }^{-1} ;{ }^{\mathrm{VII}} \%$ of total $\mathrm{N}$.

Mean values followed by different lowercase letters in the column and different uppercase letters in the row differ by Tukey's test $(\mathrm{P}<0.05)$. 
The mean $\mathrm{CE}$ value during the aerobiosis period was different $(\mathrm{P}<0.05)$ between silages (Table 2$)$, with higher values for pre-wilted mulberry silage (1192.83 $\left.\mathrm{mS} \mathrm{cm}^{-1}\right)$ and lower for mulberry silage with ear corn (961.35 $\mathrm{mS} \mathrm{cm}^{-1}$; Table 6). Fresh mulberry silage did not differ significantly from the other silages in terms of EC values $\left(1079.08 \mathrm{mS} \mathrm{cm}^{-1}\right)$. Higher values of EC were observed in legume silage due to higher concentration of soluble components and ions compared to grass silage (BAMBIERIS JUNIOR et al., 2010; LIMA-OROZCO et al., 2013), which provides an explanation for the highest EC values in pre-wilted mulberry and fresh mulberry silages. In general, wilted silage resulted in higher cell lysis than non-wilted silage, resulting in higher EC (LOURES et al., 2005). Nevertheless, this was not observed in the present study, in which the fresh mulberry silage and pre-wilted mulberry silage presented similar EC values.

There were differences between the silages in the mean $\mathrm{NH}_{3}-\mathrm{N}$ content during the aerobiosis period (Table 2), with higher $\mathrm{NH}_{3}-\mathrm{N}$ content in fresh mulberry tree silage (13.08\% total N; Table 2). Normally, foods with a high content of CP have a greater formation of ammoniacal nitrogen residues, making it difficult to reduce $\mathrm{pH}$. According to Van Soest (1994), $\mathrm{NH}_{3}-\mathrm{N}$ content below $10 \%$ of the total $\mathrm{N}$ present in silage indicates that there has been no excessive breakdown of amino acids. The $\mathrm{NH}_{3}-\mathrm{N}$ content remained below this limit in pre-wilted mulberry silage and silage with ear corn, with mean values of 7.49 and $9.58 \%$ total $\mathrm{N}$, respectively. Probably, the low water content present in these silages reduced the population of clostridia which produce $\mathrm{NH}_{3}-\mathrm{N}$, resulting in good preservation of the ensiled material.

\section{Conclusions}

Conservation of white mulberry tree as silage with $11 \%$ ground ear corn in the total dry matter presented the best nutritional value for feeding ruminants. In addition, this silage had the best fermentation pattern, with low $\mathrm{pH}$ values, which favored adequate preservation of this material. Despite the high $\mathrm{pH}$ and the high buffering capacity that the mulberry tree presents in comparison with other forages, its nutritional, physical and chemical characteristics when conserved as silage remained unchanged during the one-week period of aerobic exposure.

\section{References}

ALMEIDA, J. E.; FONSECA, T. C. Mulberry germplasm and cultivation in Brazil. In: SANCHEZ, M. D. (Ed.). Mulberry for animal production. Roma: Food and Agriculture Organization of the United Nations, 2002. p. 73-95. Available at: <http://www.fao.org/docrep/005/ X9895E/x9895e06.htm\#bm06>. Accessed at: 31 mar. 2017.

ANDRADE, A. P.; QUADROS, D. G.; BEZERRA, A. R. G.; ALMEIDA, J. A. R.; SILVA, P. H. S.; ARAÚJO, J. A. M. Aspectos qualitativos da silagem de capim-elefante com fubá de milho e casca de soja. Semina: Ciências Agrárias, Londrina, v. 33, n. 3, p. 1209-1218, 2012.

ASSOCIATION OF OFFICIAL ANALYTICAL CHEMISTS - AOAC. Official methods of analysis. $15^{\text {th }}$ ed. Arlington: AOAC International, 1990. $1117 \mathrm{p}$.

AZEVEDO, A. C. C. G.; PINHO COSTA, K. A.; COLLAO-SAENZ, E. A.; SANTOS DIAS, F. J.; SEVERIANO, E. C.; CRUVINEL, W. S. Nutritional value of Xaraés and Piatã palisadegrass silages prepared with additives or wilting. Acta Scientiarum Animal Science, Maringá, v. 36, n. 1, p. 25-31, 2015.

BAMBIERIS JUNIOR, V. H.; JOBIM, C. C.; EMILE, J. C.; ROMAN, J.; SILVA, M. S. Aerobic stability of triticale silage in single culture or in mixtures with oat and/or legumes. Revista Brasileira de Zootecnia, Viçosa, MG, v. 39, n. 11, p. 2349-2356, 2010.

CARVALHO, G. G. P.; GARCIA, R.; PIRES, A. J. V.; PEREIRA, O. G.; AZEVEDO, J. A. G.; CARVALHO, B. M. A.; CAVALI, J. Valor nutritivo de silagens de capimelefante emurchecido ou com adição de farelo de cacau. Revista Brasileira de Zootecnia, Viçosa, MG, v. 36, n. 5, p. 1495-1501, 2007.

COLLINS, M.; OWENS, V. N. Preservation of forage as hay and silage. In: BARNES, R.; NELSON, C. J.; COLLINS, M.; MOORE, K. J. Forages an introduction to grassland agriculture. $6^{\text {th }}$ ed. Iowa: Blackwell Publishing, 2003. p. 443-471. 
DORAN, M. P.; LACA, E. A.; SAINZ, R. D. Total tract and rumen digestibility of mulberry foliage (Morus alba), alfalfa hay and oat hay in sheep. Animal Feed Science and Technology, Amsterdam, v. 138, n. 3-4, p. 239-253, 2007.

EVANGELISTA, A. R.; SIQUEIRA, G. R.; LIMA, J. A.; LOPES, J.; REZENDE, A. V. Alterações bromatológicas e fermentativas durante o armazenamento de silagens de cana-de-açúcar com e sem milho desintegrado com palha e sabugo. Revista Brasileira de Zootecnia, Viçosa, MG, v. 38 , n. 1, p. 20-26, 2009.

FERRAZ, J. B. S.; FELÍCIO, P. E. Production systems - an example from Brazil. Meat Science, Amsterdam, v. 84 , n. 2, p. 238-243, 2010

FOOD AND AGRICULTURE ORGANIZATION OF THE UNITED NATIONS - FAO. The state of food and agriculture. Roma: Food and Agriculture Organization of the United Nations, 2009. 180 p. Available at: $<$ http:// www.fao.org/docrep/012/i0680e/i0680e. pdf > . Accessed at: 31 mar. 2017.

JOBIM, C. C.; NUSSIO, L. G. Princípios básicos da fermentaçãona ensilagem. In: REIS, R.A.;BERNARDES, T. F.; SIQUEIRA, G. R. (Ed.). Forragicultura: ciência, tecnologia e gestão dos recursos forrageiros. Jaboticabal: Maria de Lurdes Brandel, ME, 2013. p. 649-660.

KRAUS, T. J.; KOEGER, R. G.; STRAUB, R. J.; SHINNERS, K. Leachate conductivity as an index for quantifying level of forage conditioning. Transactions of the ASAE - American Society of Agricultural Engineers, St. Joseph, v. 42, n. 4, p. 847-852, 1999.

LIMA-OROZCO, R.; CASTRO-ALEGRÍA, A.; FIEVEZ, V. Ensiled sorghum and soybean as ruminant feed in the tropics, with emphasis on Cuba. Grass and Forage Science, Oxford, v. 68, n. 1, p. 20-32, 2013.

LOURES, D. R. S.; NUSSIO, L. G.; PAZIANI, S. F.; PEDROSO, A. F.; MARI, L. J.; RIBEIRO, J. L.; ZOPOLLATTO, M.; SCHMIDT, P.; JUNQUEIRA, M. C.; PACKER, I. U.; CAMPOS, F. P. Composição bromatológica e produção de efluente de silagens de capim-tanzânia sob efeitos do emurchecimento, do tamanho de partícula e do uso de aditivos biológicos. Revista Brasileira de Zootecnia, Viçosa, MG, v. 34, n. 3, p. 726-735, 2005.

McDONALD, P.; HENDERSON, A. R. Buffering capacity of herbage samples as a factor in ensilage. Journal of the Science of Food and Agriculture, Londres, v. 13, n. 7, p. 395-400, 1962.

McDONALD, P.; HENDERSON, A. R.; HERON, S. J. E. The biochemistry of silage. $2^{\text {th }}$ ed. Marlow: Chalcombe Pub, 1991. $340 \mathrm{p}$.
MERRY, R. J.; JONES, R.; THEODOROU, M. K. The conservation of grass. In: HOPKINS, A. (Ed.). Grass its production e utilization. $3^{\text {th }}$ ed. Oxford: Blackwell Science, 2000. p. 196-228.

PLAYNE, M. J.; McDONALD, P. The buffering constituents of herbage and of silage. Journal of the Science of Food and Agriculture, Londres, v. 17, n. 6, p. 264-268, 1966.

RANGRAB, L. H.; MÜHLBACH, P. R. F.; BERTO, J. L. Silagem de alfafa colhida no início do florescimento e submetida ao emurchecimento e à ação de aditivos biológicos. Revista Brasileira de Zootecnia, Viçosa, MG, v. 29, n. 2, p. 349-356, 2000.

RIBEIRO, J. L.; NUSSIO, L. G.; MOURÃO, G. B.; QUEIROZ, O. C. M.; SANTOS, M. C.; SCHMIDT, P. Efeitos de absorventes de umidade e de aditivos químicos e microbianos sobre o valor nutritivo, o perfil fermentativo e as perdas em silagens de capim-marandu. Revista Brasileira de Zootecnia, Viçosa, MG, v. 38, n. 2, p. 230-239, 2009.

SALINAS-CHAVIRA, J.; CASTILLO-MARTÍNEZ, O.; RAMIREZ-BRIBIESCA, J. E.; MELLADO, M. Effect of increasing levels of white mulberry leaves (Morus alba) on ruminal dry matter degradability in lambs. Tropical Animal Health and Production, Edinburgh, v. 43, n. 5, p. 995-999, 2011.

SCHMIDEK, A.; TAKAHASHI, R.; MEDEIROS, A. N.; RESENDE, K. T. Bromatological composition and degradation rate of mulberry in goats. In: SANCHEZ, M. D. (Ed.). Mulberry for animal production. Roma: Food and Agriculture Organization of the United Nations, 2002. Available at: <http://www.fao.org/docrep/ 005/ X9895E/x9895e0k.htm\#bm20>. Accessed at: 31 mar. 2017.

SILVA, D. J.; QUEIROZ, A. C. Análises de alimentos: métodos químicos e biológicos. Viçosa, MG: UFV, 2002. $235 \mathrm{p}$.

STATISTICAL ANALYSIS SYSTEM - SAS. SAS user's guide: statistics, version 9.0. Cary: SAS Institute, 2002.

TABACCO, E.; PIANO, S.; CAVALLARIN, L.; BERNARDES, T. F.; BORREANI, G. Clostridia spore formation during aerobic deterioration of maize and sorghum silages as influenced by Lactobacillus buchneri and Lactobacillus plantarum inoculants. Applied and Environmental Microbiology, Rockville Pike, v. 107, n. 5, p. 1632-1641, 2009.

TAFFAREL, L. E.; MESQUITA, E. E.; CASTAGNARA, D. D.; OLIVEIRA, P. S. R.; OLIVEIRA, N. T. E.; GALBEIRO, S.; COSTA, P. B. Produção de matéria seca e valor nutritivo do feno do Tifton 85 adubado com 
nitrogênio e colhido com 35 dias. Revista Brasileira de Saúde e Produção Animal, Salvador, v. 15, n. 3, p. 544$560,2014$.

TAYLOR, C. C.; KUNG JÚNIOR, L. The effect of Lactobacillus buchneri 40788 on fermentation and aerobic stability of high moisture corn in laboratory silos. Journal of Dairy Science, Champaing, v. 85, n. 6, p. 1526-1532, 2002.

VAN SOEST, P. J. Nutritional ecology of the ruminant. $2^{\text {th }}$ ed. London: Comstock Publishing Associates, 1994. 476 p.

VAN SOEST, P. J.; ROBERTSON, J. B.; LEWIS, B. A. Methods for dietary fiber, neutral detergent fiber, and no starch polysaccharides in relation to animal nutrition. Journal of Dairy Science, Champaing, v. 74, n. 10, p. 3583-3597, 1991.
WEISS, W. P.; CONRAD, H. R.; ST. PIERRE, N. R. A theoretically-based model for predicting total digestible nutrient values of forages and concentrates. Animal Feed Science and Technology, Amsterdam, v. 39, n. 1-2, p. 95110, 1992.

ZANINE, A. M.; SANTOS, E. M.; FERREIRA, D. J.; PEREIRA, O. G.; ALMEIDA, J. C. C. Efeito do farelo de trigo sobre as perdas, recuperação da matéria seca e composição bromatológica de silagem de capimmombaça. Brazilian Journal of Veterinary Research and Animal Science, São Paulo, v. 43, n. 6, p. 803-809, 2006.

ZOPOLLATTO, M.; DANIEL, J. L. P.; NUSSIO, L. G. Aditivos microbianos em silagens no Brasil: revisão dos aspectos da ensilagem e do desempenho dos animais. Revista Brasileira de Zootecnia, Viçosa, MG, v. 38, p. 170-189, 2009. Suplemento Especial. 
